\title{
SYNTHESIS AND SCREENING OF BENZOFURAN FUSED $C-2,4,6$-SUBSTITUTED PYRIMIDINE DERIVATIVES AS A NEW ANTIBACTERIAL AND ANTIFUNGAL AGENT
}

\author{
JAVARAPPA RANGASWAMY, NAGARAJA NAIK \\ Department of Studies in Chemistry, University of Mysore, Manasagangotri, Mysore 570006, Karnataka, India \\ Email: rangaswamyteertha@gmail.com
}

Received: 04 Feb 2017 Revised and Accepted: 13 Jul 2017

\section{ABSTRACT}

Objective: Benzofuran and their heterocyclic analogs represent an important class of molecules which have a wide range of pharmacological activities. Therefore, in this study synthesis and antimicrobial activity of benzofuran fused $C$-2,4,6-substituted pyrimidine derivatives was extensively discussed.

Methods: Benzofuran fused $C$-2,4,6-substituted pyrimidine derivatives ( $4 \mathrm{a}-\mathrm{k}$ ) were built by cyclo condensation, Claisen-Schmidt condensation followed by cyclization via coupling of benzoyl fragments, which include benzofuran, a pyrimidine ring and $C$ - 6 substituted phenyl residue with various substituents, connected by linker-S-band. The structures of the synthesized compounds were confirmed by analytical and spectral techniques and evaluated their antimicrobial activity.

Results: The results of antibacterial and antifungal activity against various microbes, most of the compounds have shown considerable antimicrobial activity, but compounds $4 \mathrm{~g}$ and $4 \mathrm{e}$ exhibits superior activity compared to standards, this may be due to presence bromo and fluro electron withdrawing substituent on the benzoyl moiety and more lipophilic nature of pyrimidine ring.

Conclusion: According to the activity studies, it is observed that the synthesis and antimicrobial activity of benzofuran fused $C$-2,4,6-substituted pyrimidine derivatives have been shown better antimicrobial activity. The obtained results suggest that these classes of compounds can be considered as new hits for further structural optimization to obtain better antimicrobial drug development program.

Keywords: Benzofuran incorporating substituted pyrimidines, Substituted benzoyl moieties, Antimicrobial activity

(C) 2017 The Authors. Published by Innovare Academic Sciences Pvt Ltd. This is an open access article under the CC BY license (http://creativecommons.org/licenses/by/4.0/) DOI: http://dx.doi.org/10.22159/ijpps.2017v9i9.17487

\section{INTRODUCTION}

The chemical and biological potentials of six-membered heterocyclic compounds fused with aromatic nuclei such as indole, benzofuran and their annulated derivatives have attracted the attention of organic and medicinal chemists for several years [1]. Amongst them, the benzofuran ring systems occupy an important place because they constitute the core skeleton of a family of structurally unique and exhibit a wide range of biological properties such as antihyperglycemic, analgesic, anti-inflammatory, antimicrobial and antitumor activities [2-4]. Various derivatives of benzofuran have been prepared and tested for their biological activity with various modifications in the substituent. The isolation of benzofuran derivatives from natural sources is laborious and time-consuming. So the synthetic chemists are interested in synthesizing the benzofuran derivatives [5]. In this context, pyrimidine derivatives attracted organic chemists very much due to their biological and chemotherapeutic importance. Synthesis of six-membered heterocyclic compounds such as pyrimidine ring is very important because of the synthetic condition and pharmacological properties [6-10]. It is noteworthy that fused heterocyclic structures containing pyrimidine ring exhibited diverse biological activities such as antimicrobial [11, 12], DNA cleavage [13], anti-inflammatory [14], antiviral [15], anti-HIV [16] and antitumor [17]. Benzofuran nucleus directly linked at $C$-2 to various substituted heterocyclic ring systems exhibited promising biological activity [18].

Fight against the microbes is never ending the battle. The harmful microbes poses the biggest problem in the society as far as health and hygiene is concerned [19]. As the resistance to antimicrobial agents increasing day by day, it is very necessary to synthesize new compounds which will show less bacterial resistance and good inhibitory activity. In view of the importance of benzofuran and pyrimidine fragment and also due to our research interests in synthesis of biologically active heterocycles [20-21], we envisioned that, the design and synthesis of benzofuran fused $C-2,4,6$ - substituted pyrimidine derivatives (fig. 1) by introduction of a benzoyl moiety to the pyrimidine S-H (4) scaffold might form a novel series of microbial inhibitors with improved potency and selectivity. Herein, we report the detailed synthesis and evaluation of antibacterial and antifungal activity of these compounds.

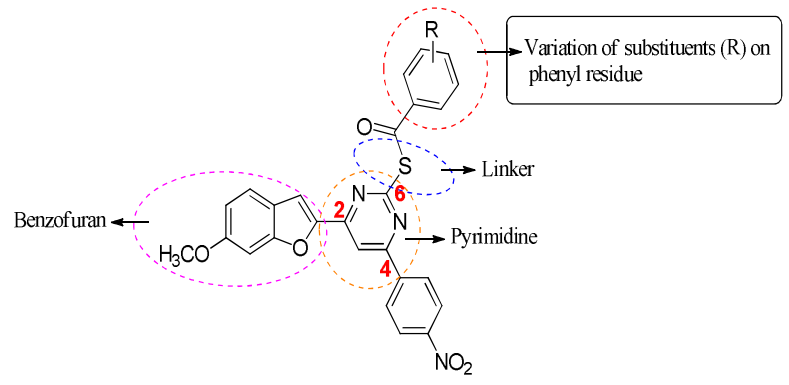

Fig. 1: General structure of title compounds (4a-k)

\section{MATERIALS AND METHODS}

\section{General}

All reagents and solvents were purchased from Merck (Darmstadt, Germany) chemical AR grade and were used as provided. TLC analysis was performed on alumina sheets precoated with silica gel 60F-254 and $\mathrm{SiO}_{2}, 200-400$ mesh (Merck) was used for column chromatography. ${ }^{1} \mathrm{H}$ NMR (400 MHz) and ${ }^{13} \mathrm{C}$ NMR (100 MHz) were obtained AC Bruker spectrometer in the appropriate (DMSO- $d_{6}$ ) solvent. Melting points were obtained on a reichert thermopan melting point apparatus, equipped with a microscope and are uncorrected. Mass spectra were obtained by Water-Q-TOF ultima 
spectrometer. Micro analytical data were obtained by elementalVario EL-III.

\section{Experimental part}

\section{General procedure}

\section{Synthesis of 1-(6-methoxy benzofuran-2-yl) ethanone (2)}

A mixture of 2-Hydroxy-4-methoxy benzaldehyde (1) (2 mmol), chloroacetone $(2 \mathrm{mmol})$ and 1,8-Diazabicyclo[5.4.0]undec-7-ene (DBU) $(2 \mathrm{mmol})$ in $10 \mathrm{ml}$ of dry dichloromethane (DCM) containing molecular sieves was refluxed for $1 \mathrm{hr}$. The progress of the reaction was monitored by TLC using hexane: ethyl acetate (8:2) mixture as the mobile phase. After the completion of the reaction, the reaction mixture was washed with $10 \% \mathrm{HCl}$ solution followed by water. The organics were dried over anhydrous sodium sulphate. The yellow solid was obtained by desolventized in a rotary evaporator at room temperature affords 1-(6-methoxy benzofuran-2-yl) ethanone (2): m. p. $127-129^{\circ} \mathrm{C}$, Yield-92\%, IR (KBr) $v_{\max }\left(\mathrm{cm}^{-1}\right): 1674(\mathrm{C}=0), 1558$ $(\mathrm{C}=\mathrm{C}), 3087$ (CH furan), $2900\left(\mathrm{CH}_{3}\right) .{ }^{1} \mathrm{H}$ NMR (DMSO- $\left.d_{6} 400 \mathrm{MHz}\right) \delta$ ppm: 6.82-7.75 (m, 4H, $\mathrm{Ar}-\mathrm{H}), 3.80\left(\mathrm{~s}, 3 \mathrm{H}, \mathrm{OCH}_{3}\right), 2.62\left(\mathrm{~s}, 3 \mathrm{H}, \mathrm{CH}_{3}\right)$; ${ }^{13} \mathrm{C}$ NMR (DMSO- $\left.d_{6} 100 \mathrm{MHz}\right) \delta \mathrm{ppm}: 185.5,161.3,155.2,143.5$, 119.2, 111.2, 103.2, 93.8, 55.2, 25.3; MS (ESI) m/z: $190.06\left(\mathrm{M}^{+}\right)$. Anal. calcd. for $\mathrm{C}_{11} \mathrm{H}_{10} \mathrm{O}_{3}, \mathrm{C}, 69.46$; $\mathrm{H}, 5.30$; found: C, C, 69.50; $\mathrm{H}, 5.26 \%$.

\section{Synthesis of (E)-1-(6-methoxy benzofuran-2-yl)-3-(4-nitrophenyl)} prop-2-en-1-one (3)

Compound (2) (1 mmol) in DCM (5 ml) was treated with $\mathrm{ZrCl}_{4}(46.6$ $\mathrm{mg}, 20 \mathrm{~mol} \%$ ) followed by addition nitro benzaldehyde (1 mmol). The solution stirred at room temperature under an air atmosphere for $1 \mathrm{hr}$. After the completion of the reaction monitored by TLC, the crude mixture was worked up in ice cold brine solution and then extracted with ethyl acetate solution $(3 \times 10 \mathrm{ml})$. The combined ethyl acetate extract was dried over anhydrous $\mathrm{Na}_{2} \mathrm{SO}_{4}$ and concentrated in vacuo and the resulting products were purified by column chromatography using ethyl acetate/n-hexane as mobile phase (7:3) to afforded the pure product (3) as a solid. The product was recrystallized by methanol. (E)-1-(6-methoxybenzofuran-2-yl)-3-(4nitrophenyl)prop-2-en-1-one (3): Light brown solid, yield 56\%, m. p.: 205-208 ${ }^{\circ} \mathrm{C}$ Spectroscopic analysis: IR $(\mathrm{KBr}) v_{\max }\left(\mathrm{cm}^{-1}\right): 3122-2961$ (Ar-CH), 1629 (C=0); ${ }^{1} \mathrm{H}$ NMR (DMSO- $\left.d_{6} 400 \mathrm{MHz}\right) \delta$ ppm: 7.32-8.20 (m, 8H, Ar-H), 7.84-7.90 (d, $1 \mathrm{H}, J=8 \mathrm{~Hz}, \beta-\mathrm{CH}), 6.93-6.95$ (d, $1 \mathrm{H}, J=8$ $\mathrm{Hz}, \alpha-\mathrm{CH}$ ), 3.73 (s, $3 \mathrm{H}, \mathrm{OCH}_{3}$ ); [13]C NMR (DMSO- $\left.d_{6} 100 \mathrm{MHz}\right) \delta \mathrm{ppm}$ : $177.3,160.2,155.6,145.1,147.1,141.3,129.0,127.8,124.5,123.6$, 123.2, 121.0, 120.8, 116.2, 111.0, 55.3; MS (ESI) m/z: $323.2\left(\mathrm{M}^{+}\right)$; Anal. calcd. for $\mathrm{C}_{18} \mathrm{H}_{13} \mathrm{NO}_{5}$ : C, 66.87; $\mathrm{H}, 4.05 ; \mathrm{N}, 4.33$; found: $\mathrm{C}, 66.85$; H, $4.09 ; \mathrm{N}, 4.29 \%$.

\section{Synthesis of 4-(6-methoxybenzofuran-2-yl)-6-(4-nitrophenyl) pyrimidine-2-thiol (4)}

Compound (3) $(0.01 \mathrm{~mol})$ and thiourea $(0.01 \mathrm{~mol})$ were dissolved in DMF $(20 \mathrm{ml})$. Few drops of concentrated $\mathrm{HCl}$ were added and the reaction mixture was refluxed and the reaction was monitored by TLC. After completion of reaction, the reaction mixture was poured onto $250 \mathrm{ml}$ of ice-cold water and kept aside for some time. The crude solid was filtered and subjected to column chromatography. Elution with solvent system ethyl acetate/hexane (20:80) gave pure compound (4). 4-(6-methoxybenzofuran-2-yl)-6-(4-nitrophenyl) pyrimidine-2-thiol (4): Reddish brown solid, yield 70\%, m. p.: 324$327{ }^{\circ} \mathrm{C}$ Spectroscopic analysis: IR $(\mathrm{KBr}) v_{\max }\left(\mathrm{cm}^{-1}\right)$ : 3130-2946 (Ar$\mathrm{CH}), 1625(\mathrm{C}=\mathrm{N}) ;{ }^{1} \mathrm{H}$ NMR (DMSO- $\left.d_{6} 400 \mathrm{MHz}\right) \delta \mathrm{ppm}: 12.5(\mathrm{~s}, 1 \mathrm{H}$, $\mathrm{SH}) ; 7.94(\mathrm{~s}, 1 \mathrm{H}, \mathrm{CH}$ of pyrimidin), 7.12-7.96 (m, 8H, Ar-H), $3.74(\mathrm{~s}$, $3 \mathrm{H}, \mathrm{OCH}_{3}$ );[13]C NMR (DMSO- $\left.d_{6} 100 \mathrm{MHz}\right) \delta$ ppm: 181.5, 166.2, 164.6, 155.4, 149.8, 147.9, 141.9, 129.3, 126.2, 124.7, 124.1, 123.4, 120.8, 111.2, 103.6, 101.9, 55.50; MS (ESI) m/z: $379.06\left(\mathrm{M}^{+}\right)$; Anal. calcd. for $\mathrm{C}_{19} \mathrm{H}_{13} \mathrm{~N}_{3} \mathrm{O}_{4} \mathrm{~S}: \mathrm{C}, 60.15 ; \mathrm{H}, 3.45 ; \mathrm{N}, 11.08$; found: $\mathrm{C}, 60.12 ; \mathrm{H}$, $3.48 ; \mathrm{N}, 11.11 \%$.

General procedure for the synthesis of benzofuran fused $C$ 2,4,6-substituted pyrimidine derivatives (4a-k)

4-(benzofuran-2-yl)-6-(4-nitrophenyl) pyrimidine-2-thiol (4) (1.2 $\mathrm{mmol}$ ) was suspended in dry THF (5 ml) in an inert atmosphere $\left(\mathrm{N}_{2}\right)$. To this suspension, at room temperature triethylamine $(1.5$ $\mathrm{mmol})$ and different benzoyl chlorides (RCOCl) $(1 \mathrm{mmol}$ in $3 \mathrm{ml}$ of THF) was added and the reaction mixture was stirred for 3-4 h. The progress of reaction mixture was monitored by TLC using ethyl acetate: hexane $(8: 2)$. The reaction mixture was then desolventized in a rotary evaporator and the compound was extracted in ethyl acetate. The ethyl acetate layer was washed with water and dried over anhydrous sodium sulphate. The products were obtained by further desolventation in a rotary evaporator at $50-60{ }^{\circ} \mathrm{C}$. The respective products were purified through column chromatography using ethyl acetate: hexane (8:2).

$S$-4-(6-methoxybenzofuran-2-yl)-6-(4-nitrophenyl) pyrimidin2-yl benzothioate (4a)

Brown solid. m. p.: 212-214 ${ }^{\circ} \mathrm{C}$ Spectroscopic analysis: IR (KBr)v ${ }_{\max }\left(\mathrm{cm}^{-1}\right): 3135-2967$ (Ar-CH), 1624 (C=N Pyrazole); ${ }^{1} \mathrm{H}$ NMR (DMSO- $\left.d_{6} 400 \mathrm{MHz}\right) \delta$ ppm: 8.45 (s, $1 \mathrm{H}, \mathrm{CH}$ of pyrimidin), 6.95-8.29 (m, 13H, Ar-H), 3.83 (s, 3H, OCH $)_{3}$; [13]C NMR (DMSO-d $\left.d_{6} 100 \mathrm{MHz}\right) \delta$ ppm: 188.3, 187.6, 166.2, 164.6, 157.6, 156.4, 149.9, 147.8, 134.7, 134.1, 128.9, 128.0, 126.2, 124.4, 121.7, 111.3, 103.4, 101.6, 96.3, 55.8; MS (ESI) m/z: $483.09\left(\mathrm{M}^{+}\right)$; Anal. calcd. for $\mathrm{C}_{26} \mathrm{H}_{17} \mathrm{~N}_{3} \mathrm{O}_{5} \mathrm{~S}$ : C, 64.59; $\mathrm{H}, 3.54 ; \mathrm{N}, 8.69$; found: C, 64.54; H, 3.57; N, 8.71\%.

$S$-4-(6-methoxybenzofuran-2-yl)-6-(4-nitrophenyl) pyrimidin2-yl 4-nitrobenzothioate (4b)

Yellow solid, m. p.: $233-235{ }^{\circ} \mathrm{C}$ Spectroscopic analysis: IR (KBr)v $\max \left(\mathrm{cm}^{-1}\right)$ : 3128-2989 (Ar-CH), $1645(\mathrm{C}=\mathrm{N}) ;{ }^{1} \mathrm{H}$ NMR (DMSO- $d_{6} 400$ MHz) $\delta$ ppm: $8.48(\mathrm{~s}, 1 \mathrm{H}, \mathrm{CH}$ of pyrimidin), 6.97-8.40 (m, 12H, Ar-H), $3.85\left(\mathrm{~s}, 3 \mathrm{H}, \mathrm{OCH}_{3}\right.$ ); [13]C NMR (DMSO-d $\left.{ }_{6} 100 \mathrm{MHz}\right) \delta \mathrm{ppm}: 188.3$, 187.4, 166.3, 164.9, 157.8, 156.2, 153.1, 149.8, 147.5, 141.9, 140.3, 129.0, 126.1, 124.4, 124.0, 121.9, 121.6, 111.3, 103.4, 101.7, 96.5, 55.8; MS (ESI) m/z: $528.06\left(\mathrm{M}^{+}\right)$; Anal. calcd. for $\mathrm{C}_{26} \mathrm{H}_{16} \mathrm{~N}_{4} \mathrm{O}_{7} \mathrm{~S}: \mathrm{C}$, $59.09 ; \mathrm{H}, 3.05 ; \mathrm{N}, 10.60$; found: C, 59.14; H, 2.98; N, 10.57\%.

$S$-4-(6-methoxybenzofuran-2-yl)-6-(4-nitrophenyl) pyrimidin2-yl 3-chlorobenzothioate (4c)

Light brown semisolid. Spectroscopic analysis: IR $(\mathrm{KBr}) v_{\max }\left(\mathrm{cm}^{-1}\right)$ : 3132-2941 (Ar-CH), 1619 (C=N); ${ }^{1} \mathrm{H}$ NMR (DMSO-d $\left.4000 \mathrm{MHz}\right) \delta$ ppm: 8.42 (s, $1 \mathrm{H}, \mathrm{CH}$ of pyrimidin), 6.95-8.30 (m, 12H, Ar-H), 3.82 (s, $3 \mathrm{H}, \mathrm{OCH}_{3}$ ); [13]C NMR (DMSO- $d_{6} 100 \mathrm{MHz}$ ) $\delta$ ppm: $188.3,187.3$, 166.0, 164.5, 157.4, 156.3, 149.7, 147.9, 141.9, 136.1, 134.4, 130.3, 126.2, 124.4, 121.8, 121.5, 111.3, 103.4, 101.6, 96.0, 55.5; MS (ESI) m/z: $517.05\left(\mathrm{M}^{+}\right)$. Anal. calcd. for $\mathrm{C}_{26} \mathrm{H}_{16} \mathrm{ClN}_{3} \mathrm{O}_{5} \mathrm{~S}$ : C, 60.29; $\mathrm{H}, 3.11 ; \mathrm{N}$, 8.11; found: C, $60.31 ; \mathrm{H}, 3.10 \mathrm{~N}, 8.15 \%$.

S-4-(6-methoxybenzofuran-2-yl)-6-(4-nitrophenyl) pyrimidin2-yl 4-hydroxybenzothioate (4d)

Light Brown solid, m. p.: $245-247{ }^{\circ} \mathrm{C}$ Spectroscopic analysis: IR $(\mathrm{KBr}) \nu_{\max }\left(\mathrm{cm}^{-1}\right): 3125-2986(\mathrm{Ar}-\mathrm{CH}), 1629$ (C=N pyrazole); ${ }^{1} \mathrm{H}$ NMR (DMSO- $\left.d_{6} 400 \mathrm{MHz}\right) \delta \mathrm{ppm}: 8.41(\mathrm{~s}, 1 \mathrm{H}, \mathrm{CH}$ of pyrimidin), 6.89-8.31 $(\mathrm{m}, 12 \mathrm{H}, \mathrm{Ar}-\mathrm{H}), 5.32(\mathrm{~s}, 1 \mathrm{H}, \mathrm{OH}), 3.83\left(\mathrm{~s}, 3 \mathrm{H}, \mathrm{OCH}_{3}\right) ;[13] \mathrm{C}$ NMR (DMSO- $\left.d_{6} 100 \mathrm{MHz}\right) \delta$ ppm: $188.4,187.5,166.2,164.6,163.9,157.6$, 156.5, 149.9, 147.8, 141.9, 129.6 127.3, 126.2, 124.4, 121.8, 116.1, 111.3, 103.2, 101.5, 96.5, 55.7; MS (ESI) m/z: $499.08\left(\mathrm{M}^{+}\right)$; Anal. calcd. for $\mathrm{C}_{26} \mathrm{H}_{17} \mathrm{ClN}_{3} \mathrm{O}_{6} \mathrm{~S}$ : C, C, 62.52; H, 3.43; N, 8.41; found: C, C, $62.50 ; \mathrm{H}, 3.45 ; \mathrm{N}, 8.40 \%$.

$S$-4-(6-methoxybenzofuran-2-yl)-6-(4-nitrophenyl) pyrimidin2-yl 4-fluorobenzothioate (4e)

Off white solid, m. p.: $302-304{ }^{\circ} \mathrm{C}$. Spectroscopic analysis: IR (KBr)v $\max \left(\mathrm{cm}^{-1}\right)$ : 3123-2988 (Ar-CH), $1655(\mathrm{C}=\mathrm{N})$; ${ }^{1} \mathrm{H}$ NMR (DMSO- $d_{6} 400$ $\mathrm{MHz}) \delta \mathrm{ppm}: 8.47$ (s, $1 \mathrm{H}, \mathrm{CH}$ of pyrimidin) $6.85-8.29$ (m, 12H, Ar-H), $3.82\left(\mathrm{~s}, 3 \mathrm{H}, \mathrm{OCH}_{3}\right) ;{ }^{13} \mathrm{C}$ NMR (DMSO- $\left.d_{6} 100 \mathrm{MHz}\right) \delta \mathrm{ppm}: 188.6,187.7$, $168.3,166.4,164.7,157.5,156.4,149.8,147.9,142.0,130.3,129.7$, 126.2, 124.4, 121.9, 115.7, 111.2, 103.4, 101.7, 96.3, 56.0; MS (ESI) m/z: $501.08\left(\mathrm{M}^{+}\right)$; Anal. calcd. for $\mathrm{C}_{26} \mathrm{H}_{16} \mathrm{FN}_{3} \mathrm{O}_{5} \mathrm{~S}$ : C, 62.27; $\mathrm{H}, 3.22 ; \mathrm{N}$, 8.38; found: C, $62.30 ; \mathrm{H}, 3.21 ; \mathrm{N}, 8.35 \%$.

$S$-4-(6-methoxybenzofuran-2-yl)-6-(4-nitrophenyl) pyrimidin2-yl 2-hydroxybenzothioate (4f)

Dark brown solid, m. p.: $218-221^{\circ} \mathrm{C}$. Spectroscopic analysis: IR (KBr)v ${ }_{\max }\left(\mathrm{cm}^{-1}\right)$ : 3129-2975 (Ar-CH), $1641(\mathrm{C}=\mathrm{N})$; ${ }^{1} \mathrm{H}$ NMR (DMSO- $\left.\mathrm{d}_{6} 400 \mathrm{MHz}\right)$ $\delta$ ppm: 8.45 (s, 1H, CH of pyrimidin), 6.96-8.30 (m, 12H, Ar-H), 5.33 (s, 
$1 \mathrm{H}, \mathrm{OH}$ ), 3.78 (s, 3H, OCH 3 ); [13]C NMR (DMSO-d $6100 \mathrm{MHz}$ ) $\delta \mathrm{ppm:}$ $188.3,187.5,166.2,164.6,160.0,157.6,156.5,149.8,147.8,141.9,135.5$, 129.5, 126.2, 124.4, 121.9, 121.5, 117.9, 111.3,103.4, 101.6, 96.5, 55.7; MS (ESI) m/z: 499.08 (M+); Anal. calcd. for $\mathrm{C}_{26} \mathrm{H}_{17} \mathrm{~N}_{3} \mathrm{O}_{6} \mathrm{~S}: \mathrm{C}, 62.52 ; \mathrm{H}, 3.43$; N, 8.41; found C, 62.50; H, 3.45; N, 8.44\%.

$S$-4-(6-methoxybenzofuran-2-yl)-6-(4-nitrophenyl) pyrimidin2-yl 4-bromobenzothioate (4g)

Brown solid. m. p.: $273-275{ }^{\circ} \mathrm{C}$, Spectroscopic analysis: IR (KBr)v $\max \left(\mathrm{cm}^{-1}\right): 3138-2963(\mathrm{Ar}-\mathrm{CH}), 1633(\mathrm{C}=\mathrm{N}) ;{ }^{1} \mathrm{H}$ NMR (DMSO- $d_{6} 400$ $\mathrm{MHz}) \delta$ ppm: 8.38 (s, $1 \mathrm{H}, \mathrm{CH}$ of pyrimidin), 6. 98-8.25 (m, 12H, Ar-H), $3.80\left(\mathrm{~s}, 3 \mathrm{H}, \mathrm{OCH}_{3}\right.$ ); [13]C NMR (DMSO- $\left.d_{6} 100 \mathrm{MHz}\right) \delta \mathrm{ppm}: 188.4$, $187.3,166.5,164.3,157.5,149.8,147.6,141.8,137.0,136.8,131.6$, 129.9, 127.1, 126.2, 124.4, 123.2, 121.9, 121.6, 111.0, 103.2, 101.6, 96.3, 55.8; MS (ESI) m/z: $563.00\left(\mathrm{M}^{+}\right)$. Anal. calcd. for $\mathrm{C}_{26} \mathrm{H}_{16} \mathrm{BrN}_{3} \mathrm{O}_{5} \mathrm{~S}$ : C, 55.53; H, 2.87; N, 7.47; found: C, 55.55; H, 2.84; N, 7.50\%.

\section{$S$-4-(6-methoxybenzofuran-2-yl)-6-(4-nitrophenyl) pyrimidin-} 2-yl 4-methylbenzothioate (4h)

Dark yellow solid, m. p.: $217-219{ }^{\circ} \mathrm{C}$. Spectroscopic analysis: IR (KBr)v $\max \left(\mathrm{cm}^{-1}\right)$ : 3128-2984 (Ar-CH), $1626(\mathrm{C}=\mathrm{N})$; ${ }^{1} \mathrm{H}$ NMR (DMSO- $d_{6} 400 \mathrm{MHz}$ ) $\delta$ ppm: 8.41 (s, 1H, CH of pyrimidin), 7.05-8.30 (m, 12H, Ar-H), 3.82 (s, $\left.3 \mathrm{H}, \mathrm{OCH}_{3}\right), 2.34\left(\mathrm{~s}, 3 \mathrm{H}, \mathrm{CH}_{3}\right.$ ); [13]C NMR (DMSO-d $\left.d_{6} 100 \mathrm{MHz}\right) \delta \mathrm{ppm}:$ 188.5, 187.4, 166.0, 164.5, 157.6, 156.4, 149.7, 147.6, 143.8, 141.8, 131.7, 129.2, 128.0, 126.1, 124.3, 121.8, 111.2, 103.2, 101.8, 95.8, 55.3, 21.3; MS (ESI) m/z: : $497.10\left(\mathrm{M}^{+}\right)$; Anal. calcd. for $\mathrm{C}_{27} \mathrm{H}_{19} \mathrm{~N}_{3} \mathrm{O} 5 \mathrm{~S}: \mathrm{C}, 65.18 ; \mathrm{H}, 3.85 ; \mathrm{N}$, 8.45; found: $\mathrm{C}, 65.20$; $\mathrm{H}, 3.79$; $\mathrm{N}, 8.42 \%$

$S$-4-(6-methoxybenzofuran-2-yl)-6-(4-nitrophenyl) pyrimidin2-yl 2-methoxy-4-nitrobenzothioate (4i)

Yellow semisolid. Spectroscopic analysis: IR $(\mathrm{KBr}) v_{\max }\left(\mathrm{cm}^{-1}\right): 3259-$ 2935 (Ar-CH), 1637 (C=N); ${ }^{1}$ HMR (DMSO-d $6400 \mathrm{MHz}$ ) $\delta$ ppm: 8.35 (s, $1 \mathrm{H}, \mathrm{CH}$ of pyrimidin), 6.95-8.20 (m, $11 \mathrm{H}, \mathrm{Ar}-\mathrm{H}), 3.83(\mathrm{~s}, 6 \mathrm{H}$,

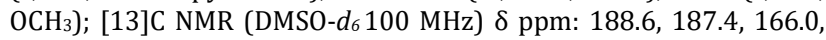
$164.5,160.2$, 157.6, 156.7, 154.2, 149.8, 147.9, 141.6, 130.0, 126.3, 124.5, 121.8, 121.6, 116.4, 112.7, 111.3, 103.4, 101.6, 96.0, 55.8; MS (ESI) m/z: $558.08\left(\mathrm{M}^{+}\right)$; Anal. calcd. for $\mathrm{C}_{27} \mathrm{H}_{18} \mathrm{~N}_{4} \mathrm{O}_{8} \mathrm{~S}$ : C, 58.06; $\mathrm{H}$, 3.25; N, 10.03; found: C, 58.06; H, 3.25; N, 10.03\%.

\section{$S$-4-(6-methoxybenzofuran-2-yl)-6-(4-nitrophenyl) pyrimidin-} 2-yl 4-methoxybenzothioate (4j)

Off white solid, m. p.: $258-261^{\circ} \mathrm{C}$. Spectroscopic analysis: IR (KBr)v $\max \left(\mathrm{cm}^{-1}\right)$ : 3263-2955 (Ar-CH), $1632(\mathrm{C}=\mathrm{N})$; ${ }^{1} \mathrm{H}$ NMR (DMSO- ${ }_{6} 400$ $\mathrm{MHz}) \delta$ ppm: 8.42 (s, $1 \mathrm{H}, \mathrm{CH}$ of pyrimidin), 7.00-8.36 (m, 12H, Ar-H), $3.80\left(\mathrm{~s}, 6 \mathrm{H}, \mathrm{OCH}_{3}\right)$; [13]C NMR (DMSO- $\left.d_{6} 100 \mathrm{MHz}\right) \delta \mathrm{ppm}: 188.4$, $187.5,166.1,166.0,164.6,157.6,156.4,149.8,147.8,141.8,129.0$, 127.0, 126.2, 124.4, 121.8, 114.5, 111.3, 103.5, 101.6, 96.2, 55.8; MS (ESI) $\mathrm{m} / \mathrm{z}: 513.10\left(\mathrm{M}^{+}\right)$; Anal. calcd. for $\mathrm{C}_{27} \mathrm{H}_{19} \mathrm{~N}_{3} \mathrm{O}_{6} \mathrm{~S}$ : C, 63.15; $\mathrm{H}$, 3.73; N, 8.18; found: C, 63.18; H, 3.69; N, 8.20\%.

\section{S-4-(6-methoxybenzofuran-2-yl)-6-(4-nitrophenyl) pyrimidin-} 2-yl 3-hydroxy-4-methoxybenzothioate (4k)

Brown solid. m. p.: $219-221^{\circ} \mathrm{C}$ Spectroscopic analysis: IR $(\mathrm{KBr}) v_{\max }(\mathrm{Cm}-$ 1): 3130-2960 (Ar-CH), 1634 (C=N); ${ }^{1} \mathrm{H}$ NMR (DMSO- $\left.d_{6} 400 \mathrm{MHz}\right) \delta \mathrm{ppm}$ : 8.38 (s, 1H, CH of pyrimidin), 7.09-8.29 (m, 11H, Ar-H), $5.02(\mathrm{~s}, 1 \mathrm{H}, \mathrm{OH})$, $3.81\left(\mathrm{~s}, 6 \mathrm{H}, \mathrm{OCH}_{3}\right) ;{ }^{13} \mathrm{C}$ NMR (DMSO- $\left.d_{6} 100 \mathrm{MHz}\right) \delta \mathrm{ppm:} 188.3,187.4$, $166.1,164.6,157.6,156.5,155.5,149.9,147.8,147.4,141.8,128.4,126.5$, 124.4, 121.8, 114.8, 112.4, 111.0, 103.2, 101.6, 96.2, 56.1, 55.7; MS (ESI) m/z: $529.09\left(\mathrm{M}^{+}\right)$; Anal. calcd. for $\mathrm{C}_{27} \mathrm{H}_{19} \mathrm{~N}_{3} \mathrm{O}_{7} \mathrm{~S}: \mathrm{C}, 61.24 ; \mathrm{H}, 3.62 ; \mathrm{N}, 7.94$; found: C, 61.26; H, 3.60; N, 7.95\%.

\section{Biological evaluation}

\section{Antibacterial activity}

The antibacterial activities of newly synthesized compounds (4a-k) were determined by well plate method in Mueller-Hinton Agar [22, 23].

The antibacterial activity was carried out against $24 \mathrm{~h}$ old cultures of bacterial strains. The test compounds were dissolved in dimethyl sulfoxide (DMSO) at a concentration of 1000 and $500 \mu \mathrm{g} / \mathrm{ml} .20 \mathrm{ml}$ of sterilized agar media was poured into each pre-sterilized Petri dish. Excess of the suspension was decanted and plates were dried by placing them in an incubator at $37^{\circ} \mathrm{C}$ for an hr. About $60 \mathrm{ml}$ of 24 $\mathrm{h}$ old culture suspension were poured and neatly swabbed with the pre-sterilized cotton swabs. Six-millimeter diameter well was then punched carefully using a sterile cork borer and $30 \mathrm{ml}$ of test solutions of different concentrations were added into each labeled well. The plates were then incubated at $37^{\circ} \mathrm{C}$ for $24 \mathrm{~h}$. The inhibition zone that appeared after $24 \mathrm{~h}$, around the well in each plate was measured as a zone of inhibition in mm. Experiments were carried out in triplicates and the standard deviation was calculated.

\section{Antifungal activity}

Antifungal studies of newly synthesized compounds (4a-k) were carried out against A. flavus, C. keratinophilum and C. albicans. Sabourand's agar media was prepared by dissolving peptone (10 g), Dglucose $(40 \mathrm{~g})$ and agar $(20 \mathrm{~g})$ in distilled water $(1000 \mathrm{ml})$ and adjusting the $\mathrm{pH}$ to 5.7. Normal saline was used to make a suspension of spore of fungal strains for lawning. A loopful of particular fungal strain was transferred to $3 \mathrm{ml}$ saline to get a suspension of the corresponding species. $20 \mathrm{ml}$ of agar media was poured into each Petri dish. Excess of the suspension was decanted and plates were dried by placing them in an incubator at $37^{\circ} \mathrm{C}$ for $1 \mathrm{hr}$. Wells were made on these seeded agar plates using sterile cork borer and different concentrations of the test compounds in DMSO were added into each of the labelled wells. A control was also prepared for the plates, in the same way, using DMSO. The Petri dishes were prepared in triplicate and maintained at $25{ }^{\circ} \mathrm{C}$ for $72 \mathrm{~h}$. Antifungal activity was determined by measuring the diameter of inhibition zone. The activity of each compound was compared with fluconazole as standard. Zones of inhibition were determined for compounds (4a-k).

\section{RESULTS AND DISCUSSION}

\section{Chemistry}

Scheme 1 and 2 illustrate the synthetic pathway to benzofuran fused $C$-2,4,6-substituted pyrimidine derivatives. Preparation of compounds was started from the methoxy-salicylaldehyde (1) that underwent cyclo condensation reaction with chlroacetone in DCM at room temperature by using DBU as the base thus obtaining intermediates 1-(6-methoxy benzofuran-2-yl) ethanone (2) [24]. Chalcone was synthesized from the (2) with nitro benzaldehyde by Claisen-Schmidt condensation under zirconium chloride as a catalyst thus yielding (3) [25]. Generally, chalcones are considered to be useful intermediate in several cyclisation reactions to produce types of heterocyclic compounds of diverse biological importance, according to the reactants used and the reaction conditions [26]. Construction of the 4-(benzofuran-2-yl)-6-(4-nitrophenyl) pyrimidine-2-thiol (4) was achieved by cyclization of compound (3) with thiourea following a Keri protocol [27]. The moderate yield obtained with the used Keri protocol was considered acceptable for our purposes. Finally, the target compounds (4a-k) were obtained by coupling of commercially available benzoyl chlorides fragments to compound (4) contain linker bond S-H. According to this, 4(benzofuran-2-yl)-6-(4-nitrophenyl) pyrimidine-2-thiol was coupled with various substituent's containing benzoyl chlorides, under basic conditions and conversion of the corresponding benzofuran fused $C$ 2,4,6-substituted pyrimidine derivatives ( $4 \mathrm{a}-\mathrm{k})$ and reported in table 1. The structures of the compounds were elucidated by IR, ${ }^{1} \mathrm{H}$ NMR, ${ }^{13} \mathrm{C}$ NMR, mass and elemental analysis.

\section{Antimicrobial studies}

\section{Antibacterial activity}

The results of antibacterial activities revealed that the majority of the synthesized compounds showed varying degree of inhibition against tested microorganisms. Compared with the standard streptomycin, the antibacterial potency of compounds (4e) and (4g) was found to be the highest against all bacterial strains (table 2). According to the Structure-Activity Relationship (SAR), it is clear that initially, key scaffold (4) showed the considerable activity due to the presence of electron withdrawing nitro group on the pyrimidine $C-4$ substituted phenyl ring. Further, the introduction of benzoyl moieties influences for effective increases in the activity. Among the synthesized compounds fluro, and bromo substituents on benzoyl moieties to pyrimidine core is more active than the other analogues. The reason would be more lipophilic nature of 
pyrimidine moiety [28] along with the presence of electronegative groups like halogens. The compounds (4e) and (4g) showed pronounced antibacterial activity. Whereas compounds (4b), (4c), (4h), (4i) and (4j) have also demonstrated good activity because of chloro, nitro, methyl and methoxy substituted benzoyl chloride within the same ring system. The other analogues (4d), (4f) and (4k) it was noticed that the introduction of hydroxy substituted benzoyl chlorides to compound (4) not favors for enhanced antibacterial activity.

It is concluded that the presence of 4-fluorobenzoyl chloride or 4bromo benzoyl chloride substitution to S-H bond of pyrimidine ring system causes a significant increase in antibacterial activity.

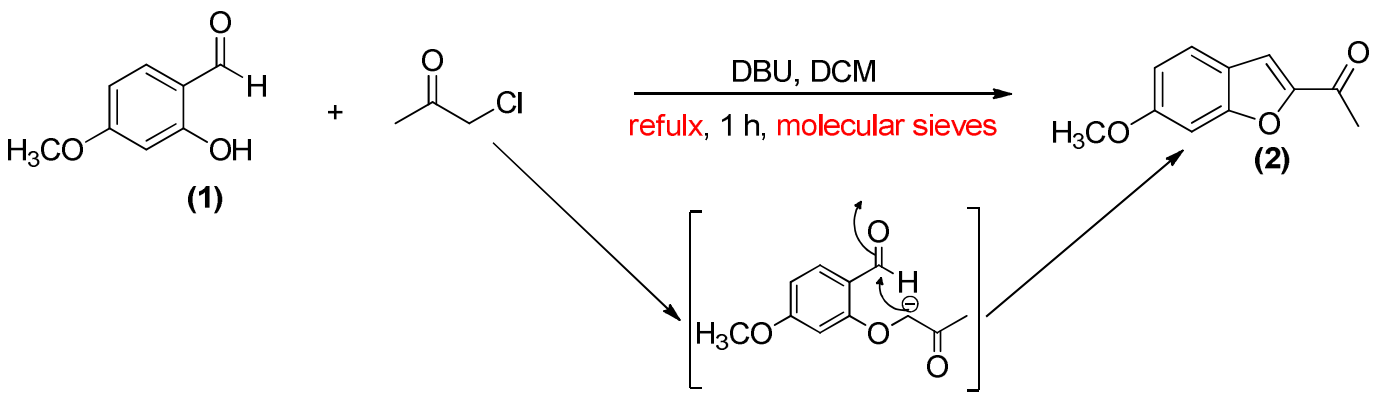

(a)

Scheme 1: Synthesis of 1-(6-methoxybenzofuran-2-yl) ethanone (2)<smiles>COc1ccc2cc(C(C)=O)oc2c1</smiles>

(2)<smiles>COc1ccc2cc(C(=O)/C=C/c3ccc([N+](=O)[O-])cc3)oc2c1</smiles><smiles>COc1ccc2cc(-c3cc(-c4ccc([N+](=O)[O-])cc4)nc(S)n3)oc2c1</smiles>

(4)

(4a-k)<smiles></smiles>

Scheme 2: Synthesis pathway for benzofuran fused $C$-2,4,6-substituted pyrimidine derivatives (4a-k)

\section{Antifungal activity}

The antifungal screening revealed that some of the tested compounds showed good inhibition against various tested fungal strains (table 3). Initially, key intermediates $(3,4)$ showed considerable activity. Further, introduction of benzoyl moieties into the pyrimidine ring accounted for the enhanced activity. It is to be noted that the nature of the substituent present on the phenyl ring of benzoyl terminus was found to have the strongest influence on the activity and this was confirmed by the fact that the presence of electron withdrawing bromo and fluro group in compounds (4g and
$4 \mathrm{e})$ displayed excellent activity than the standard fluconazole. Compounds (4b), (4c), (4h), (4i) and (4j) have also exhibited good activity because of chloro, nitro, methyl and methoxy functional group at para and meta position on phenyl ring of benzoyl terminus. From the studies, the analogues holding electron donating hydroxyl, methyl and methoxy groups were not demanded for enhanced activity against all bacterial strains. This might be the reason for decreases the activity in compounds (4d), (4f) and (4k) compared to other analogues. It is concluded antifungal investigation demonstrated that the halogen and nitro substituents was the source for the significant increases in the activity. 
Table 1: Chemical structures and yields of synthesized compounds (4a-k)

\begin{tabular}{|c|c|c|c|c|c|}
\hline $\begin{array}{l}\text { Compound } \\
\text { number }\end{array}$ & $\mathbf{R}$ & Yield \% & Compound number & $\mathbf{R}$ & Yield \% \\
\hline $4 \mathrm{a}$ & & 71.56 & $4 \mathrm{~g}$ & & 75.85 \\
\hline $4 b$ & & 73.23 & $4 \mathrm{~h}$ & & 71.70 \\
\hline $4 c$ & & 61.59 & $4 \mathrm{i}$ & & 73.45 \\
\hline $4 d$ & & 77.10 & $4 \mathrm{j}$ & & 74.21 \\
\hline $4 e$ & & 65.54 & $4 \mathrm{k}$ & & \\
\hline $4 f$ & & 75.23 & & & \\
\hline
\end{tabular}

Table 2: Inhibitory zone (diameter) mm of the synthesized compounds (4a-k) against tested bacterial strains by well plate method

\begin{tabular}{|c|c|c|c|c|c|c|}
\hline \multirow{2}{*}{$\begin{array}{l}\text { Compound } \\
\text { Concentration } \\
(\mu \mathrm{g} / \mathrm{ml})\end{array}$} & \multicolumn{2}{|c|}{ Escherichia coli } & \multicolumn{2}{|c|}{ Staphylococcus aureus } & \multicolumn{2}{|c|}{ Pseudomonas aeroginosa } \\
\hline & 1000 & 500 & 1000 & 500 & 1000 & 500 \\
\hline $4 a$ & $4 \pm 0.02$ & $3 \pm 0.03$ & $2 \pm 0.01$ & $1 \pm 0.01$ & $3 \pm 0.02$ & $2 \pm 0.02$ \\
\hline $4 b$ & $4 \pm 0.01$ & $3 \pm 0.01$ & $3 \pm 0.02$ & $1 \pm 0.01$ & $3 \pm 0.03$ & $3 \pm 0.01$ \\
\hline $4 c$ & $4 \pm 0.01$ & $4 \pm 0.01$ & $4 \pm 0.01$ & $2 \pm 0.02$ & $6 \pm 0.01$ & $4 \pm 0.02$ \\
\hline $4 d$ & $7 \pm 0.01$ & $5 \pm 0.01$ & $6 \pm 0.02$ & $4 \pm 0.02$ & $6 \pm 0.02$ & $5 \pm 0.01$ \\
\hline $4 \mathrm{e}$ & $18 \pm 0.01$ & $15 \pm 0.02$ & $17 \pm 0.01$ & $09 \pm 0.01$ & $17 \pm 0.03$ & $13 \pm 0.02$ \\
\hline $4 \mathrm{f}$ & $8 \pm 0.03$ & $5 \pm 0.01$ & $6 \pm 0.02$ & $5 \pm 0.01$ & $9 \pm 0.02$ & $6 \pm 0.01$ \\
\hline $4 g$ & $19 \pm 0.04$ & $17 \pm 0.01$ & $18 \pm 0.02$ & $13 \pm 0.03$ & $19 \pm 0.02$ & $16 \pm 0.04$ \\
\hline $4 \mathrm{~h}$ & $7 \pm 0.01$ & $6 \pm 0.03$ & $9 \pm 0.04$ & $7 \pm 0.02$ & $5 \pm 0.01$ & $3 \pm 0.03$ \\
\hline $4 \mathrm{i}$ & $6 \pm 0.01$ & $5 \pm 0.03$ & $4 \pm 0.01$ & $2 \pm 0.01$ & $5 \pm 0.02$ & $3 \pm 0.01$ \\
\hline $4 j$ & $6 \pm 0.01$ & $4 \pm 0.01$ & $4 \pm 0.02$ & $3 \pm 0.02$ & $3 \pm 0.02$ & $1 \pm 0.01$ \\
\hline $4 \mathrm{k}$ & $5 \pm 0.01$ & $3 \pm 0.01$ & $3 \pm 0.02$ & $2 \pm 0.02$ & $4 \pm 0.02$ & $3 \pm 0.02$ \\
\hline Streptomycin & $18 \pm 0.01$ & $10 \pm 0.01$ & $15 \pm 0.02$ & $10 \pm 0.01$ & $18 \pm 0.01$ & $12 \pm 0.02$ \\
\hline
\end{tabular}

Each value represents mean $\pm \operatorname{SD}(n=3)$

Table 3: Inhibitory zone (diameter) $\mathrm{mm}$ of the synthesized compounds (4a-k) against tested fungal strains by well plate method

\begin{tabular}{|c|c|c|c|c|c|c|}
\hline \multirow{2}{*}{$\begin{array}{l}\text { Compound } \\
\text { Concentration } \\
(\mu \mathrm{g} / \mathrm{ml})\end{array}$} & \multicolumn{2}{|c|}{ Aspergillus flavus } & \multicolumn{2}{|c|}{ Chrysosporium keratinophilum } & \multicolumn{2}{|c|}{ Candida albicans } \\
\hline & 1000 & 500 & 1000 & 500 & 1000 & 500 \\
\hline $4 \mathrm{a}$ & $3 \pm 0.01$ & $1 \pm 0.02$ & $4 \pm 0.03$ & $3 \pm 0.02$ & $4 \pm 0.03$ & $3 \pm 0.02$ \\
\hline $4 \mathrm{~b}$ & $4 \pm 0.02$ & $1 \pm 0.01$ & $4 \pm 0.02$ & $3 \pm 0.02$ & $5 \pm 0.02$ & $3 \pm 0.01$ \\
\hline $4 c$ & $3 \pm 0.01$ & $1 \pm 0.01$ & $5 \pm 0.02$ & $3 \pm 0.01$ & $3 \pm 0.01$ & $2 \pm 0.03$ \\
\hline $4 d$ & $6 \pm 0.01$ & $5 \pm 0.01$ & $5 \pm 0.01$ & $2 \pm 0.01$ & $5 \pm 0.02$ & $4 \pm 0.01$ \\
\hline $4 \mathrm{e}$ & $15 \pm 0.01$ & $13 \pm 0.02$ & $18 \pm 0.01$ & $16 \pm 0.04$ & $23 \pm 0.01$ & $21 \pm 0.01$ \\
\hline $4 \mathrm{f}$ & $6 \pm 0.02$ & $5 \pm 0.01$ & $4 \pm 0.01$ & $3 \pm 0.01$ & $5 \pm 0.03$ & $4 \pm 0.02$ \\
\hline $4 \mathrm{~g}$ & $16 \pm 0.03$ & $14 \pm 0.01$ & $20 \pm 0.02$ & $18 \pm 0.01$ & $25 \pm 0.01$ & $23 \pm 0.01$ \\
\hline $4 h$ & $5 \pm 0.01$ & $4 \pm 0.01$ & $3 \pm 0.01$ & $3 \pm 0.01$ & $5 \pm 0.02$ & $3 \pm 0.04$ \\
\hline $4 \mathrm{i}$ & $5 \pm 0.01$ & $3 \pm 0.02$ & $5 \pm 0.02$ & $4 \pm 0.02$ & $4 \pm 0.01$ & $2 \pm 0.01$ \\
\hline $4 j$ & $4 \pm 0.02$ & $2 \pm 0.01$ & $5 \pm 0.02$ & $4 \pm 0.01$ & $3 \pm 0.02$ & $4 \pm 0.02$ \\
\hline $4 \mathrm{k}$ & $4 \pm 0.01$ & $1 \pm 0.02$ & $4 \pm 0.01$ & $3 \pm 0.02$ & $4 \pm 0.01$ & $2 \pm 0.01$ \\
\hline Fluconazole & $13 \pm 0.01$ & $12 \pm 0.02$ & $17 \pm 0.02$ & $16 \pm 0.01$ & $22 \pm 0.02$ & $20 \pm 0.02$ \\
\hline
\end{tabular}

Each value represents mean $\pm \operatorname{SD}(n=3)$ 


\section{CONCLUSION}

In the present article, we have reported the in situ synthesis of benzofuran fused $C-2,4,6$-substituted pyrimidine derivatives (4a-k) by choosing proper experimental conditions and investigate for antibacterial and antifungal activity with the hope of discovering new structure leads serving as potential broad spectrum pharmacological agents. The structure activity relationship studies revealed the critical role of halogens function in the target compounds at para position of benzoyl phenyl ring that showed very promising antimicrobial activity. Compounds $(4 \mathrm{~g})$ and $(4 \mathrm{e})$ contains bromo and fluro on the benzoyl moiety were demonstrated significant antimicrobial activity compared to standard. These results could be helpful in further design and discovery of more potent antimicrobial inhibitors.

\section{ACKNOWLEDGEMENT}

The authors are grateful to the University Grants Commission, Government of India, for granting UGC-Post Doctoral FellowshipPDFSS and UGC-SAP-DRS-III.

\section{AUTHORS' CONTRIBUTION}

Javarappa Rangaswamy researched and wrote this article. Nagaraja Naik provided guidance, critical review, and revision.

\section{CONFLICT OF INTERESTS}

The authors declare that they have no conflict of interest

\section{REFERENCES}

1. Simpson TJ. Advanc Heterocycl Chem Academic: London; 1984;35:2-81.

2. Mustafa A. Furopyrans and Furopyrones; John Wiley and Sons: Chapter III: Furochromones, New York; 1967.

3. Gammill RB, Hyde BR. Total synthesis of the lipid-altering and antiatherosclerotic furochromone khellin. The furoic acid route to highly functionalized benzofurans. J Org Chem 1983;48:3863-5.

4. Kim S, Salim AA, Swanson SM, Kinghorn AD. Potential of cyclopenta[b]benzofurans from Aglaia species in cancer chemotherapy. Adv Anticancer Agents Med Chem 2006;6:319-45.

5. Lavanya A, Sribalan R, Padmini V. Synthesis and biological evaluation of new benzofuran carboxamide derivatives. J Saudi Chem Soc 2015;1-9. http://dx.doi. org/10.1016/j. jscs. 2015. 06.008.

6. Basawaraj R, Hugar MH, Sangapure SS. Synthesis and biological evaluation of benzofuro [3, 2-d] pyrimidones. Indian J Hetero Chem 2009;18:329-32.

7. Ostrowski S. Approaches to fused pyrimidine derivatives by the pyrimidine construction and their application to synthesis of purines. Pol J Chem 2001;75:1661-87.

8. Kidwai M, Deo Mishra A. An expeditious synthesis of 3,4dihydrobenzo[2,3 d]pyrimidines using inorganic solid supports. J Serb Chem Soc 2004;69:247-54.

9. Balzarini J, McGuigan C. Bicyclic pyrimidine nucleoside analogues (BCNAs) as highly selective and potent inhibitors of varicella-zoster virus replication. J Antimicrob Chemother 2002;50:5-9.

10. Lednicer D. Strategies for organic drugs synthesis and design, Chapters 8 and 9 Wiley, New York; 1998.

11. Manna F, Chimenti F, Fioravanti R, Bolasco A, Secci D, Chimenti $\mathrm{P}$, et al. Synthesis of some pyrazoles derivatives and preliminary investigation of their affinity binding to $p$ gylcoprotein. Bioorg Med Chem Lett 2005;15:4632-5.

12. Jantova S, Stankovsky S, Spirkova K. In vitro antibacterial activity of ten series of substituted quinazolines. Biologia Bratislava 2004;59:741-52.

13. Biradar JS, Sasidhar BS, Parveen R. Synthesis, antioxidant and DNA cleavage activities of novel indole derivatives. Eur J Med Chem 2010;45:4074-8.
14. Harinadhababu V, Manna SK, Srinivasan KK, Bhat VG. Synthesis and biological evaluation of 1,3,5-trisubstituted pyrazolines bearing benzofurans. Indian J Heterocycl Chem 2004;13:253-6.

15. Nagaraja GK, Prakash GK, Satyanarayan ND, Vaidya VP, Mahadevan KM. Synthesis of novel 2-aryl-2,3-dihydronaphtho[ 2,1-b]furo[3,2-b]pyridin-4(1H)-ones of biological importance. Arkivoc 2006;15:142-52.

16. Maruyama T, Kozai S, Demizu Y, Witvrouw M, Pannecouque C, Balzarini J, et al. Synthesis and anti-HIV-1 and anti-HCMV activity of 1-substituted 3-(3,5-dimethylbenzyl)uracil derivatives. Chem Pharm Bull Jpn 2006;54:325-33.

17. Naito H, Ohsuki S, Sugimori M, Atsumi R, Minami M, Nakamura $\mathrm{Y}$, et al. Synthesis and antitumor activity of novel pyrimidinyl pyrazole derivatives. II. Optimization of the phenylpiperazine moiety of 1-[5-methyl-1-(2-pyrimidinyl)-4-pyrazolyl]-3-phenyl piperazinyl-1-trans-propenes. Chem Pharm Bull Jpn 2002:50;453-62.

18. Rida SM, EI-Hawash SA, Fahmy HT, Hazza AA, El-Meligy MM. Synthesis and in vitro evaluation of some novel benzofuran derivatives as potential anti-HIV-1, anticancer and antimicrobial agents. Arch Pharm Res 2006;29:16-25.

19. Shankar B, Shailendra S, Navanath K. Synthesis of aryl (5substituted benzofuran-2-yl) carbamate derivatives as antimicrobial agents. Asian J Pharm Clin Res 2017;10:377-81.

20. Rangaswamy J, Kumar HV, Harini ST, Naik N. Synthesis of benzofuran based 1,3,5-substituted pyrazole derivatives: as a new class of potent antioxidants and antimicrobials-A novel accost to amend biocompatibility. Bioorg Med Chem Lett 2012;22:4773-7.

21. Rangaswamy J, Kumar HV, Harini ST, Naik N. An easy eccess to benzofurans via DBU Induced condensation reaction of active 2-hydroxy acetophenones with phenacyl chlorides: A novel class of antioxidant agents. J Heterocycl Chem 2015;52:938-43.

22. Arthington-Skaggs BA, Motley M, Warnock DW, Morrison CJ. Comparative evaluation of PASCO and national committee for clinical laboratory standards M27-A broth microdilution methods for antifungal drug susceptibility testing of yeasts. J Clin Microbiol 2000;38:2254-60.

23. Mac Lowry DJ, Jaqua MJ, Selepak ST. Detailed methodology and implementation of a semiautomated serial dilution microtechnique for antimicrobial susceptibility testing. Appl Microbiol 1970;20:46-53.

24. Rangaswamy J, Kumar HV, Harini ST, Naik N. Synthesis of novel benzofuran-gathered C-2,4,6-substituted pyrimidine derivatives conjugated by sulfonyl chlorides: orally bioavailable, selective, effective antioxidants and antimicrobials drug candidates. J Heterocycl Chem 2015;52:1349-60.

25. Atul $\mathrm{K}$, Akanksha. Zirconium chloride catalyzed efficient synthesis of 1,3-diaryl-2-propenones in solvent free conditions via aldol condensation. J Mol Catal A: Chem 2007;274:212-6.

26. Yadav PP, Gupta P, Chaturvedi AK, Skukla PK, Maurya R. Synthesis of 4-hydroxy-1-methylindole and benzo[b]thiophen4-ol based unnatural flavonoids as new class of antimicrobial agents. Bioorg Med Chem 2005;13:1497-505.

27. Keri RS, Hosamani KM, Hugar MH. Analgesic, anti-pyretic and DNA cleavage studies of novel pyrimidine derivatives of coumarin moiety. Eur J Med Chem 2010;45:2597-605.

28. Andre R, Andrew TP, Sherry FQ. 2,4-diaminothieno[2,3d]pyrimidine lipophilic antifolates as inhibitors of pneumocystis carinii and toxoplasma gondii dihydrofolate reductase. J Med Chem 1997;40:3694-9.

\section{How to cite this article}

- Javarappa Rangaswamy, Nagaraja Naik. Synthesis and screening of benzofuran fused $C-2,4,6$-substituted pyrimidine derivatives as a new antibacterial and antifungal agent. Int J Pharm Pharm Sci 2017;9(9):27-32. 